\title{
Phenotypic factors affecting coagulation properties of milk from Sarda ewes
}

\author{
M. Pazzola, ${ }^{* 1}$ M. L. Dettori, ${ }^{*}$ C. Cipolat-Gotet, $†$ A. Cecchinato, $†$ G. Bittante,† and G. M. Vacca* \\ *Department of Veterinary Medicine, University of Sassari, Via Vienna 2, 07100 Sassari, Italy \\ †Department of Agronomy, Food, Natural Resources, Animals and Environment (DAFNAE) University of Padova, \\ viale dell'Università 16 - 35020 Legnaro (PD), Italy
}

\begin{abstract}
In this study, milk-coagulation properties (MCP) were characterized in the Sarda sheep breed. Milk composition and MCP [rennet-coagulation time (RCT), curd-firming time [time to reach a curd firmness of 20 $\left.\mathrm{mm}\left(\mathrm{k}_{20}\right)\right]$, and curd firmness $\left(\mathrm{a}_{30}\right),\left(\mathrm{a}_{45}\right)$, and $\left.\left(\mathrm{a}_{60}\right)\right]$ were obtained extending the lactodynamographic analysis from 30 to 60 min from a population of 1,121 ewes from 23 different farms. Managerial characteristics of farms and parity, individual daily milk yields and stage of lactation of ewes were recorded. Data were analyzed using a mixed-model procedure with fixed effects of days in milk, parity, daily milk yield, and flock size and the random effect of the flock/test day nested within flock size. Sampled farms were classified as small $(<300$ ewes) and medium (300 to 600 ewes), and these were kept by family operations, or as large (>600 ewes), often operated through hired workers. Daily milk yield was, on average, $1.58 \pm 0.79 \mathrm{~L} / \mathrm{d}$ and variability for this trait was very high. The average content of fat, protein, and casein was respectively $6.41,5.39$, and $4.20 \%$. The class of flock size had a significant effect only on curd firmness, whereas days in milk affected RCT and $\mathrm{k}_{20}$. The flock test day, parity, and daily milk yield were important sources of variation for all MCP. The mean value of RCT ( $8.6 \mathrm{~min})$ and the low occurrence of noncoagulating samples $(0.44 \%)$ confirmed the excellent coagulation ability of sheep milk compared with cattle milk. A more rapid coagulation was observed in midlactating, primiparous, and high-yielding ewes. The $\mathrm{k}_{20}$ was usually reached in less than 2 min after gelation, with the most favorable values at mid lactation. The mean value of curd firmness 30 min after rennet addition $\left(\mathrm{a}_{30}\right)$ was, on average, $50 \mathrm{~mm}$ and decreased to 46 and $42 \mathrm{~mm}$ respectively after $45\left(\mathrm{a}_{45}\right)$ and $60 \mathrm{~min}\left(\mathrm{a}_{60}\right)$. The decreasing value of curd-firmness traits was likely to be caused by curd syneresis and whey expulsion. The correlation between RCT and $\mathrm{a}_{30}$ was much lower than
\end{abstract}

Received March 14, 2014

Accepted July 9, 2014.

${ }^{1}$ Corresponding author: pazzola@uniss.it in dairy cows and about null for $\mathrm{a}_{45}$ and $\mathrm{a}_{60}$. This means that curd firmness in dairy ewes is almost independent of gelation time and this can provide specific information for this species. In conclusion, this study showed that milk from Sarda sheep is characterized by an earlier gelation, a faster increase in curd firmness with time, and greater curd firmness after 30 min compared with dairy cows. Furthermore, correlations between MCP in sheep are much lower than in bovines and some of the assumptions and interpretations related to cows cannot be applied to sheep.

Key words: sheep milk, coagulation property, Sarda sheep breed, flock characteristic

\section{INTRODUCTION}

Milk-coagulation properties (MCP) are generally used in the dairy industry to assess the suitability of milk for cheese making and predict yield and technological characteristics of cheese. Since the 1970s, many techniques have been investigated and both mechanical and infrared-based instruments have been assembled to obtain MCP (Cipolat-Gotet et al., 2012). One of the most commonly used mechanical instruments is the Formagraph (Foss Electric A/S, Hillerød, Denmark). It is able to provide a diagram that graphically illustrates the sequences of formation and development of curd after the addition of rennet (usually for $30 \mathrm{~min}$ ) and it allows the measurement of $3 \mathrm{MCP}$ : rennet-coagulation time (RCT; measured in min), curd-firming time [time to reach a curd firmness of $20 \mathrm{~mm}\left(\mathbf{k}_{\mathbf{2 0}}\right)$; $\mathrm{min}$ ], and curd-firmness $\left(\mathbf{a}_{\mathbf{3 0}} ; \mathrm{mm}\right)$ traits (McMahon and Brown, 1982). Milk-coagulation properties have been extensively studied in dairy cows and the effects of the breed, milk genetic variants, and measurement methods as well as repeatability, heritability, and genetic correlations with milk quality traits have recently been reviewed by Bittante et al. (2012).

Milk-coagulation properties of milk from small ruminants, and particularly from sheep, are much less known. Milk production from dairy sheep farming is of great economic importance, especially in the countries of Southern Europe and the Mediterranean basin in 
general (Vacca et al., 2010; Ramos and Juarez, 2011). The European Union produced about 2.8 million tonnes of ewe milk in 2011, representing $29 \%$ of the whole world ovine milk production (FAOSTAT, 2013). This milk is mainly produced by local breeds, such as in Sardinia, a region of Italy in the center of the Mediterranean Sea, where it has been estimated that $5 \%$ of the whole world ewe's milk is produced by its indigenous breed, the Sarda sheep (Vacca et al., 2008).

The Sarda is a dairy specialized breed, well adapted to the difficult environment of the island of Sardinia (Macciotta et al., 1999) where farming is characterized by a large variation in the application of semi-extensive and semi-intensive methods (Carta et al., 2009). Nowadays, the Sarda is the top-ranked sheep breed in Italy, with an estimated total population size of about 3 million head (Carta et al., 2009), among which 220,000 animals in 1,000 farms are officially recorded (ICAR, 2013). Milk from Sarda ewes is almost completely used to produce 3 protected designation of origin cheeses, according to the rules of the European Union: Pecorino Romano (EU, 2009), Pecorino Sardo, and Fiore Sardo (EU, 1996). In contrast to cattle, MCP are scarcely used as a tool to characterize milk for protected designation of origin dairy products and for milk payment scales (Bittante et al., 2011a,b).

To our knowledge, no study has yet investigated ovine MCP under field conditions and on the basis of a large sampled population. Hence, the objectives of this paper were to (1) characterize traditional MCP of the Sarda sheep breed obtained using the Formagraph instrument $\left(\mathrm{RCT}, \mathrm{k}_{20}\right.$, and $\left.\mathrm{a}_{30}\right) ;(2)$ analyze curd firmness after the standard interval of $30 \mathrm{~min}$ [i.e., at $45\left(\mathbf{a}_{45}\right)$ and $60 \mathrm{~min}$ $\left(\mathbf{a}_{60}\right)$ by extending the duration of the analysis to 60 min; (3) investigate the effect of management, feeding, and farming system on MCP, using the flock size as a statistical indicator; and (4) investigate individual effects, such as parity, stage of lactation, and daily milk yield, on a large population on MCP.

\section{MATERIALS AND METHODS}

\section{Animals and Milk Sampling}

The study involved 1,121 ewes reared in 23 different farms, evenly distributed over the whole island of Sardinia, Italy. Farms were chosen among those officially registered in the flock book of the Sarda breed and were generally managed following the common semiextensive and semi-intensive methods as described by Carta et al. (2009) and Carcangiu et al. (2011). In brief, lactating ewes were pasture fed, with a commercial concentrate supplementation given during the milkings, which were performed by manually operated milking machines twice per day (often at 0600 and at $1600 \mathrm{~h}$ ); reproduction was based on natural mating or, rarely, on AI, and lambs were milk fed by their dams and weaned when they were about 1 mo old.

A report regarding general characteristics of sampled flocks, such as geographical location, flock size, and working environment description, management, and feeding conditions is summarized in Table 1. On the basis of management and feeding characteristics, farms were classified in 3 categories: (1) traditional semiextensive farming with free-ranging pasture, (2) presence of cultivated grasslands and rotational pasture and control of the lambing season, or (3) modern semiintensive farming with investments made in new buildings and facilities, use of TMR, and advice provided by consultants and experts in animal feeding. Scores were assigned by one skilled technician to minimize error of subjective criteria.

Groups of ewes ranging in size from 32 to 82 were sampled per flock (1 sampling day for each flock). Ewes presenting clinical symptoms of disease, those within 60 $\mathrm{d}$ after parturition (often feeding their lambs), and those after $7 \mathrm{mo}$ of lactation were excluded. The sampled ewes were selected to represent the different levels of parities, DIM, and daily milk yield. The selected ewes were daughters of 120 different sires (with a minimum of 4 and a maximum of 40 daughters per sire).

During the afternoon milking, individual milk samples were collected from each ewe in 200-mL disposable sterile plastic containers and, on the same day, daily milk yield (morning plus evening milking) was recorded. Milk samples were kept at $4^{\circ} \mathrm{C}$ and analyzed within $24 \mathrm{~h}$ after collection.

\section{Analysis of Milk Traits and Coagulation Properties}

The chemical composition (fat, protein, casein, lactose, urea, and $\mathrm{pH}$ ) of individual milk samples was analyzed using a MilkoScan FT6000 milk analyzer (Foss Electric A/S), casein number (\%) was calculated as the ratio between casein and protein contents, and SCC was determined with a Fossomatic 5000 somatic cell counter (Foss Electric A/S) and total bacterial count (TBC) with a BactoScan FC150 analyzer (Foss Electric A/S) according to International Dairy Federation methods [IDF (2006) and IDF (2000), respectively]. Both SCC and TBC were logarithmically transformed to normalize the distribution: SCC to SCS, as proposed by Ali and Shook (1980), and TBC to logarithmic bacterial count $\left[\mathrm{TBC}=\log _{10}(\right.$ total bacterial count $\left./ 1,000)\right]$.

Measures of MCP were obtained using a Formagraph (Foss Italia S.P.A., Padova, Italy). For each individual sample, $10 \mathrm{~mL}$ was heated to $35^{\circ} \mathrm{C}$ before the addition of $200 \mu \mathrm{L}$ of rennet solution [Hansen Naturen Plus 215 
Table 1. Characteristics of sampled farms according to flock size

\begin{tabular}{|c|c|c|c|}
\hline Item $^{1}$ & \multicolumn{3}{|c|}{ Flock size } \\
\hline Farms, no. & 8 & 7 & 8 \\
\hline Sampled ewes, no. & 335 & 361 & 425 \\
\hline \multicolumn{4}{|l|}{ Geographical area, no. of farms } \\
\hline Plains $(<200 \mathrm{~m}$ asl $)$ & 1 & 1 & 6 \\
\hline Family-operated farms, no. & 8 & 6 & 2 \\
\hline \multicolumn{4}{|c|}{ Type of management and feeding, no. of farms } \\
\hline Traditional $^{2}$ & 5 & 1 & 0 \\
\hline Intermediate $^{3}$ & 2 & 6 & 2 \\
\hline Modern ${ }^{4}$ & 1 & 0 & 6 \\
\hline
\end{tabular}

(Pacovis Amrein AG, Bern, Switzerland), with $80 \pm 5 \%$ chymosin and $20 \pm 5 \%$ pepsin; 215 international milk clotting units (IMCU)/mL; diluted to $1.2 \%$ (wt/vol) in distilled water to achieve $0.0513 \mathrm{IMCU} / \mathrm{milk} \mathrm{mL}$ ]. This analysis continued for $60 \mathrm{~min}$ after rennet addition and the following coagulation traits were recorded: $\mathrm{RCT}$ (min), as the period from rennet addition to gel formation (bifurcation of the line); $\mathrm{k}_{20}$ (min), as the interval between gel formation and the time at which the width of the graph attains $20 \mathrm{~mm}$; and curd firmness ( $\mathrm{mm}$ ), defined by the distance between the 2 arms at $30\left(\mathrm{a}_{30}\right)$, $45\left(\mathrm{a}_{45}\right)$, and $60 \mathrm{~min}\left(\mathrm{a}_{60}\right)$ after rennet addition. In milk samples that did not coagulate $(\mathrm{n}=5)$ or coagulated more than 30 min $(\mathrm{n}=10)$ after rennet addition, $\mathrm{RCT}$ was considered to be missing, whereas $\mathrm{k}_{20}$ was labeled as missing when it occurred after $5 \min (\mathrm{n}=10)$ as well as when milk samples reached a curd firmness of $20 \mathrm{~mm}$ later than 60 min after rennet addition $(\mathrm{n}=9)$. Curd firmness was considered as a missing observation when the result was $0\left(\mathrm{a}_{30}: \mathrm{n}=15 ; \mathrm{a}_{45}: \mathrm{n}=10 ; \mathrm{a}_{60}: \mathrm{n}=7\right)$.

\section{Statistical Analysis}

Preliminary analyses showed that because the number of flocks sampled (23) and the classification criteria of individual flocks (flock size, geographical area, type of operation, and type of farm on the basis of management and feeding characteristics) were highly correlated, only one of the above factors could be included in the model to avoid multicollinearity problems. The flock size was found to be the factor producing the better model fitting according to the Akaike information criterion (Akaike, 1969; Agresti, 2002).
Data were analyzed using PROC MIXED of SAS (SAS Institute Inc., Cary, NC) according to the following linear model:

$$
\begin{aligned}
& y_{i j k l m n o}=\mu+\text { Flock size }_{m}+\text { Flock}(\text { Flock size })_{n: m} \\
& +\operatorname{DIM}_{i}+\text { parity }_{j}+\mathrm{MUCM}_{k}+\mathrm{MY}_{l}+e_{i j k l m n o}
\end{aligned}
$$

where $y_{i j k l m n o}$ is the observed trait; $\mu$ is the overall intercept of the model; Flock size ${ }_{m}$ is the fixed effect of the $m$ th flock dimension, as a statistical indicator of management, feeding, and farming system $(i=1$ to 3 ; class 1: $<300$ ewes; class 2: 300 to 600 ewes; class 3: $>600$ ewes); Flock(Flock size) $)_{n: m}$ is the random effect of the flock test day nested within flock size; $\mathrm{DIM}_{i}$ is the fixed effect of the $i$ th class of DIM ( $i=1$ to 8; class 1: 61 to $80 \mathrm{~d}$; class 2: 81 to $100 \mathrm{~d}$; class 3: 101 to $120 \mathrm{~d}$; class 4: 121 to 140 d; class 5: 141 to 160 d; class 6: 161 to 180 d; class 7: 181 to $200 \mathrm{~d}$; class 8: $>200 \mathrm{~d}$ ); parity $_{j}$ is the fixed effect of the $j$ th parity of the ewes $(j=1$ to 5 or more); $\mathrm{MUCM}_{k}$ is the fixed effect of the $k$ th measuring unit of the coagulation meter $(k=$ individual pendulum 1 to 10); $\mathrm{MY}_{l}$ is the fixed effect of $l$ th class of single test-day milk yield ( $l=1$ to 7 ; class $1:<0.60$; class 2 : 0.60 to 0.99 ; class 3: 0.99 to 1.38 ; class $4: 1.39$ to 1.77 ; class 5: 1.78 to 2.17 ; class 6 : 2.18 to 2.57 ; class 7 : $>2.57$ ); and $e_{i j k l m n o}$ is the random residual. The flock test day nested within flock size and residuals were assumed to be independently and normally distributed with a mean of zero and variance $\sigma_{F}^{2}$ and $\sigma_{e}^{2}$, respectively. The Flock(Flock size) $)_{\text {n:m }}$ was used as the error term to test the significance of flock size ${ }_{m}$, whereas all the other fixed effects were tested on residual variance. 
Table 2. Descriptive statistics of milk yield and composition of Sarda ewes

\begin{tabular}{|c|c|c|c|c|c|}
\hline Item & No. & Mean & $\mathrm{SD}$ & $\mathrm{P} 5^{1}$ & $\mathrm{P} 95^{1}$ \\
\hline Parity, no. & 1,121 & 2.30 & 1.36 & 1 & 5 \\
\hline DIM, d & 1,120 & 140 & 42 & 78 & 205 \\
\hline Daily milk yield, $\mathrm{kg} / \mathrm{d}$ & 1,111 & 1.58 & 0.79 & 0.33 & 3.27 \\
\hline Fat, $\%$ & 1,107 & 6.41 & 1.10 & 4.71 & 8.40 \\
\hline Protein, \% & 1,109 & 5.39 & 0.62 & 4.54 & 6.58 \\
\hline Casein, $\%$ & 1,107 & 4.20 & 0.51 & 3.49 & 5.16 \\
\hline Casein number, \% & 1,100 & 77.87 & 1.28 & 75.76 & 79.84 \\
\hline Lactose, \% & 1,106 & 4.82 & 0.28 & 4.31 & 5.24 \\
\hline Urea, mg/100 mL & 1,105 & 31.81 & 11.08 & 13.80 & 50.80 \\
\hline $\mathrm{pH}$ & 885 & 6.67 & 0.08 & 6.54 & 6.82 \\
\hline $\mathrm{SCS}^{2}{ }^{2} \mathrm{U}$ & 1,120 & 4.71 & 2.13 & 2.04 & 9.23 \\
\hline $\mathrm{TBC},{ }^{3} \mathrm{U}$ & 1,039 & 2.53 & 0.96 & 1.04 & 4.23 \\
\hline
\end{tabular}

The percentage of variance explained by the flock was calculated by dividing the corresponding component of variance by the total variance. Relationships among the different MCP traits as well as among residuals of the same traits were investigated.

Finally, contrasts were estimated between least squares means of MCP for the effect of (1) DIM: (a) linear, (b) quadratic, and (c) cubic component; (2) parity: (a) primiparous vs. pluriparous, (b) second parity vs. third to fifth parity, (c) third parity vs. fourth or fifth parity, and (d) fourth parity vs. fifth parity; and (3) daily milk production: (a) linear, (b) quadratic, and (c) cubic component.

\section{RESULTS}

\section{Characteristics of Sampled Farms and Individual Milk Samples}

The main features of Sardinian farms sampled for this study are summarized in Table 1. About one-third of farms were classified as small ( $<300$ ewes), one-third as medium (300 to 600 ewes), and the remaining onethird as large ( $>600$ ewes).

Small flocks had an average number of 204 dairy ewes and were distributed almost entirely in the hills and mountains of the island (the average altitude was 371 $\mathrm{m}$ above sea level). All small flocks were kept by family operations and used traditional management and feeding techniques.

The flocks of medium size had, on average, 439 dairy ewes and were distributed almost exclusively in the hilly areas of the island $(307 \mathrm{~m}$ above sea level). They were mainly family operated and used traditional techniques innovated by the use of rotational pasture on cultivated grasslands.
Last, the large flocks had an average of 894 heads of dairy ewes; they were mainly located in the plains of the island and were often operated by hired workers, and used modern facilities and feeding techniques. Descriptive statistics of sampled ewes and milk samples are shown in Table 2.

Daily milk yield was, on average, $1.58 \mathrm{~L} / \mathrm{d}$, but variability for this trait was very high. The average content of fat, protein. and casein was 6.41, 5.39, and $4.20 \%$, respectively; the variability for fat was almost double that of protein and casein content. The casein number, which is the percentage ratio between casein and protein contents, was on average $77.87 \%$, with low variability. Low variability existed for lactose content and $\mathrm{pH}$ and a comparatively high variability for urea, SCS, and TBC.

The distribution of data according to the different MCP is shown in Figure 1, in addition to their mean values and standard deviations and also coefficients of kurtosis and skewness. Both time intervals (RCT and $k_{20}$ ) were leptokurtic and right skewed, whereas the 3 measures of curd firmness moved from the leptokurtic and left-skewed distribution recorded 30 min after rennet addition to the distribution more close to a Gaussian feature recorded after $1 \mathrm{~h}$.

The correlation coefficients between the different MCP are presented in Table 3. Correlations estimated using the raw data were very similar to those calculated between the residuals obtained after correcting the raw data for the flock/test day, parity, DIM, and milk yield of ewes according to model [1]. It was also apparent that the correlations between the 2 time intervals and among the 3 measures of curd firmness were all positive and showed high values, whereas those between the time intervals and the curd-firmness measures were negative or close to zero. 

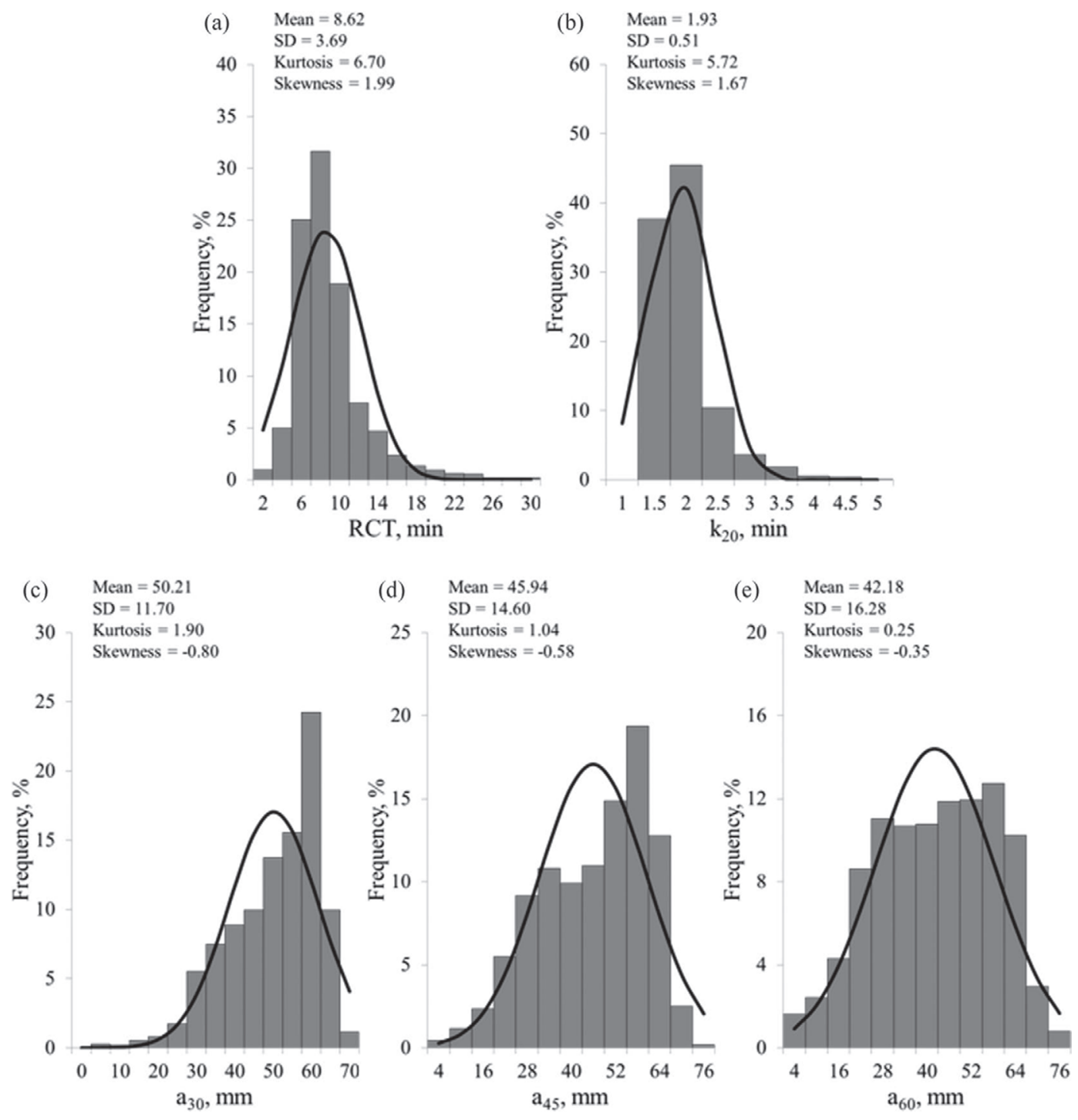

Figure 1. Distribution, mean, SD, kurtosis, and skewness of (a) rennet coagulation time (RCT), (b) curd-firming time ( $\mathrm{k}_{20}$ ), and curd firmness measured (c) $30 \mathrm{~min}\left(\mathrm{a}_{30}\right)$, (d) $45 \mathrm{~min}\left(\mathrm{a}_{45}\right)$, and (e) $60 \mathrm{~min}\left(\mathrm{a}_{60}\right)$ after rennet addition to milk samples of 1,121 Sarda ewes (skewness and kurtosis were estimated using model residuals).

Table 3. Pearson product-moment correlations between coagulation traits above the diagonal and between their residuals (according to the model including Flock/test day, parity, DIM, and milk yield of ewes) below the diagonal

\begin{tabular}{|c|c|c|c|c|c|}
\hline \multirow[b]{2}{*}{ Item } & \multicolumn{2}{|c|}{ Coagulation time, ${ }^{1} \min$} & \multicolumn{3}{|c|}{ Curd firmness, ${ }^{2} \mathrm{~mm}$} \\
\hline & $\mathrm{RCT}$ & $\mathrm{k}_{20}$ & $a_{30}$ & $\mathrm{a}_{45}$ & $a_{60}$ \\
\hline $\mathrm{RCT}$ & - & $0.65^{* * *}$ & $-0.15^{* * *}$ & $0.02^{\mathrm{NS}}$ & $-0.01^{\mathrm{NS}}$ \\
\hline $\mathrm{k}_{20}$ & $0.69^{* * *}$ & - & $-0.50 * * *$ & $-0.31^{* * *}$ & $-0.27^{* * *}$ \\
\hline $\mathrm{a}_{30}$ & $-0.23^{* * *}$ & $-0.45^{* * *}$ & - & $0.87^{* * *}$ & $0.76^{* * *}$ \\
\hline $\mathrm{a}_{45}$ & $0.03^{\mathrm{NS}}$ & $-0.20^{* * *}$ & $0.79^{* * *}$ & - & $0.92^{* * *}$ \\
\hline $\mathrm{a}_{60}$ & $0.01^{\mathrm{NS}}$ & $-0.16^{* * *}$ & $0.63^{* * *}$ & $0.88^{* * *}$ & - \\
\hline
\end{tabular}

${ }^{1} \mathrm{RCT}=$ rennet-coagulation time; $\mathrm{k}_{20}=$ curd-firming time (time to reach a curd firmness of $20 \mathrm{~mm}$ ).

${ }^{2} \mathrm{a}_{30}=30$ min after rennet addition; $\mathrm{a}_{45}=45 \mathrm{~min}$ after rennet addition; $\mathrm{a}_{60}=60 \mathrm{~min}$ after rennet addition. $* * * P<0.001$. 


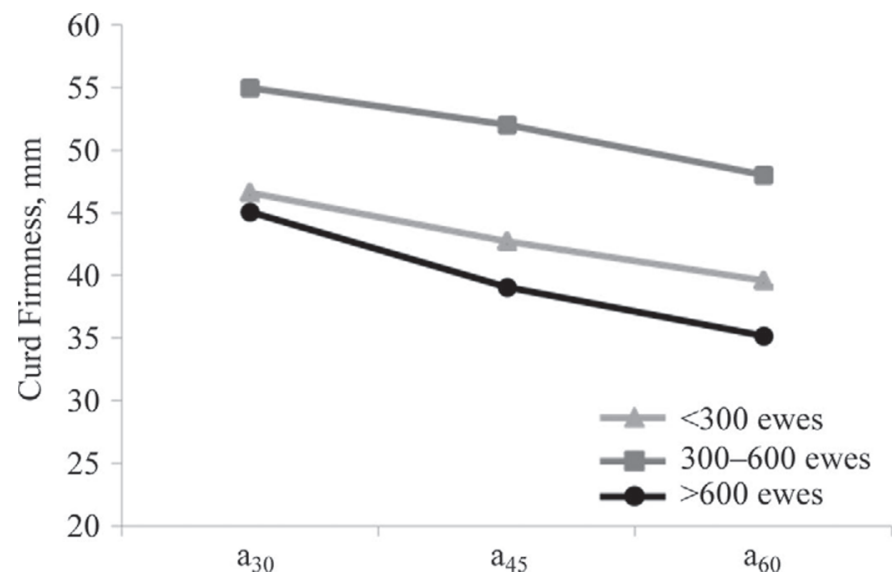

Figure 2. Effect of flock size on curd firmness of Sarda ewes (the contrasts between large and small flock size were not significant, whereas the contrasts between medium and the average of small and large flock size were significant for all curd firmness values). $\mathrm{a}_{30}, \mathrm{a}_{45}$, and $\mathrm{a}_{60}=$ curd firmness measured 30,45 , and 60 min after rennet addition, respectively.

\section{Factors Affecting Milk Coagulation Properties}

The results of statistical analyses carried out on MCP data of milk samples from Sarda ewes are shown in Table 4 . The class of flock size, which was tested as the variability among flocks within class, had a significant effect only on curd-firmness measures (Figure 2).

The flock test day was an important source of variation for all MCP (Table 4), varying from 20 to $21 \%$ of total variance in the case of the time intervals ( $\mathrm{RCT}$ and $\mathrm{k}_{20}$ ) to almost the double that value (39\%) for $\mathrm{a}_{30}$. Days in milk affected the 2 time intervals and not the measures of curd firmness (Table 4). Both time intervals showed a curvilinear response (significant quadratic contrast) to DIM (Table 5). Indeed, both traits showed the most favorable results at mid lactation (121 to 140 DIM), when the shorter $\mathrm{k}_{20}$ resulted in a rapid increase in curd firmness during the first stages of the monitored period of lactation (also the linear contrast was significant). The linear contrast of DIM was significant also for $\mathrm{a}_{30}$ and $\mathrm{a}_{45}$, showing a tendency for an increase in curd firmness during lactation.

Parity was, in general, a significant source of variation for only RCT (Table 4), but the orthogonal contrast between primiparous and multiparous ewes reached statistical significance also for $\mathrm{k}_{20}$ and $\mathrm{a}_{30}$ (Table 6). On the contrary, none of the contrasts between different parities of multiparous ewes was significant.

Also daily milk yield affected the 2 time intervals and especially the $\mathrm{a}_{30}$ (Table 4). Rennet coagulation time showed a linear improvement (reduction) with an increase in daily milk yield (Table 7). An improvement of $\mathrm{k}_{20}$ (reduction) and $\mathrm{a}_{30}$ (increase) was also recorded for high-yielding ewes, but for both traits, the improvement was more evident moving from low to intermediate milk yield than from intermediate to high levels (linear and quadratic response).

The individual position of milk samples within the 10 rack positions of the instrument was also statistically significant for all MCP except RCT (Table 4). Similar results have been obtained for dairy cows (Ikonen et al., 2004; Tyrisevä et al., 2004; Cipolat-Gotet et al., 2012) and confirmed the low reproducibility of amplitude measurements of the different pendulums. As a result, position of the pendulums should be considered when MCP data are statistically analyzed.

\section{DISCUSSION}

\section{$R C T$}

Bittante et al. (2012), in a review on modeling and genetics of MCP, report that, with the exception of

Table 4. Results from ANOVA ( $F$-value and significance) for milk coagulation properties of Sarda ewes

\begin{tabular}{|c|c|c|c|c|c|c|}
\hline \multirow[b]{2}{*}{ Item } & \multirow[b]{2}{*}{ df } & \multicolumn{2}{|c|}{ Coagulation time, ${ }^{1}$ min } & \multicolumn{3}{|c|}{ Curd firmness, ${ }^{2} \mathrm{~mm}$} \\
\hline & & $\mathrm{RCT}$ & $\mathrm{k}_{20}$ & $\mathrm{a}_{30}$ & $\mathrm{a}_{45}$ & $\mathrm{a}_{60}$ \\
\hline Flock size, $F$-value & 2 & $0.54^{\mathrm{NS}}$ & $0.40^{\mathrm{NS}}$ & $4.08^{*}$ & $4.77^{*}$ & $4.41 *$ \\
\hline Flock/test day ${ }^{3}$ & 20 & 0.21 & 0.20 & 0.39 & 0.35 & 0.28 \\
\hline DIM, $F$-value & 7 & $3.35^{* *}$ & $2.92^{* *}$ & $1.38^{\mathrm{NS}}$ & $1.33^{\mathrm{NS}}$ & $0.81^{\mathrm{NS}}$ \\
\hline Parity, $F$-value & 4 & $2.40^{*}$ & $2.03^{\mathrm{NS}}$ & $2.05^{\mathrm{NS}}$ & $0.78^{\mathrm{NS}}$ & $0.49^{\mathrm{NS}}$ \\
\hline dMY, ${ }^{4} F$-value & 6 & $2.14^{*}$ & $2.62^{*}$ & $4.62^{* * *}$ & $1.89^{\mathrm{NS}}$ & $1.59^{\mathrm{NS}}$ \\
\hline MUCM,$^{5} F$-value & 9 & $1.27^{\mathrm{NS}}$ & $8.65^{* * *}$ & $16.77^{* * *}$ & $15.13^{* * *}$ & $14.45^{* * *}$ \\
\hline $\mathrm{RMSE}^{6}$ & $1,048-1,056$ & 3.31 & 0.46 & 8.71 & 11.12 & 13.04 \\
\hline
\end{tabular}

${ }^{1} \mathrm{RCT}=$ rennet-coagulation time; $\mathrm{k}_{20}=$ curd-firming time (time to reach a curd firmness of $20 \mathrm{~mm}$ ).

${ }^{2} \mathrm{a}_{30}=30 \mathrm{~min}$ after rennet addition; $\mathrm{a}_{45}=45 \mathrm{~min}$ after rennet addition; $\mathrm{a}_{60}=60$ min after rennet addition.

${ }^{3}$ Flock/test day effect expressed as the proportion of the variance explained by flock/test date within flock size on the total variance.

${ }^{4}$ Daily milk yield.

${ }^{5}$ Measuring unit of the coagulation meter (individual pendulum 1 to 10).

${ }^{6}$ Root means square error.

${ }^{*} P<0.05 ;{ }^{* *} P<0.01$; *** $P<0.001$. 
Table 5. Least squares means of milk coagulation properties of Sarda ewes across classes of days in milk

\begin{tabular}{|c|c|c|c|c|c|c|}
\hline Item & Ewes, no. & \multicolumn{2}{|c|}{ Coagulation time, ${ }^{1}$ min } & \multicolumn{3}{|c|}{ Curd firmness, ${ }^{2} \mathrm{~mm}$} \\
\hline \multicolumn{7}{|l|}{ DIM } \\
\hline$\overline{81}-100 \mathrm{~d}$ & 131 & 8.81 & 2.08 & 47.85 & 43.18 & 40.60 \\
\hline $101-120 \mathrm{~d}$ & 231 & 8.88 & 2.02 & 48.83 & 44.48 & 40.79 \\
\hline $121-140 \mathrm{~d}$ & 149 & 8.08 & 1.89 & 49.24 & 45.58 & 41.78 \\
\hline $181-200 \mathrm{~d}$ & 159 & 9.62 & 1.93 & 49.40 & 45.28 & 41.00 \\
\hline$>200 \mathrm{~d}$ & 76 & 10.28 & 2.05 & 48.97 & 45.03 & 40.79 \\
\hline \multicolumn{7}{|l|}{ Contrast, $P$-value } \\
\hline Linear & & NS & ** & $*$ & $*$ & NS \\
\hline Quadratic & & $* *$ & $*$ & NS & NS & NS \\
\hline Cubic & & NS & NS & NS & NS & NS \\
\hline
\end{tabular}

${ }^{1} \mathrm{RCT}=$ rennet-coagulation time; $\mathrm{k}_{20}=$ curd-firming time (time to reach a curd firmness of $20 \mathrm{~mm}$ ).

${ }^{2} \mathrm{a}_{30}=30 \mathrm{~min}$ after rennet addition; $\mathrm{a}_{45}=45 \mathrm{~min}$ after rennet addition; $\mathrm{a}_{60}=60$ min after rennet addition.

$* P<0.05 ;{ }^{* *} P<0.01$.

Table 6. Least squares means of milk coagulation properties of Sarda ewes across parities

\begin{tabular}{|c|c|c|c|c|c|c|}
\hline \multirow[b]{2}{*}{ Item } & \multirow[b]{2}{*}{ Ewes, no. } & \multicolumn{2}{|c|}{ Coagulation time,${ }^{1} \min$} & \multicolumn{3}{|c|}{ Curd firmness, ${ }^{2} \mathrm{~mm}$} \\
\hline & & $\mathrm{RCT}$ & $\mathrm{k}_{20}$ & $\mathrm{a}_{30}$ & $\mathrm{a}_{45}$ & $\mathrm{a}_{60}$ \\
\hline 1 & 459 & 8.49 & 1.91 & 50.25 & 45.90 & 41.97 \\
\hline 2 & 214 & 8.97 & 1.99 & 47.80 & 44.26 & 40.89 \\
\hline 3 & 207 & 9.12 & 2.03 & 48.78 & 44.56 & 41.45 \\
\hline 4 & 116 & 9.81 & 2.05 & 48.70 & 44.72 & 40.71 \\
\hline \multicolumn{7}{|l|}{ Contrast, $P$-value } \\
\hline $\mathrm{P} 1$ vs. $\mathrm{P} 2+\mathrm{P} 3+\mathrm{P} 4+\mathrm{P} 5$ & & $*$ & $* *$ & $*$ & NS & NS \\
\hline $\mathrm{P} 2$ vs. $\mathrm{P} 3+\mathrm{P} 4+\mathrm{P} 5$ & & NS & NS & NS & NS & NS \\
\hline $\mathrm{P} 3$ vs. $\mathrm{P} 4+\mathrm{P} 5$ & & NS & NS & NS & NS & NS \\
\hline $\mathrm{P} 4$ vs. P5 & & NS & NS & NS & NS & NS \\
\hline
\end{tabular}

${ }^{1} \mathrm{RCT}=$ rennet-coagulation time; $\mathrm{k}_{20}=$ curd-firming time (time to reach a curd firmness of $20 \mathrm{~mm}$ ).

${ }^{2} \mathrm{a}_{30}=30$ min after rennet addition; $\mathrm{a}_{45}=45 \mathrm{~min}$ after rennet addition; $\mathrm{a}_{60}=60 \mathrm{~min}$ after rennet addition.

${ }^{*} P<0.05 ;{ }^{* *} P<0.01$.

Table 7. Least squares means of milk coagulation properties of Sarda ewes across classes of daily milk yield (dMY)

\begin{tabular}{|c|c|c|c|c|c|c|}
\hline Item & Ewes, no. & \multicolumn{2}{|c|}{ Coagulation time, ${ }^{1}$ min } & \multicolumn{3}{|c|}{ Curd firmness, ${ }^{2} \mathrm{~mm}$} \\
\hline \multicolumn{7}{|l|}{$\mathrm{dMY}, \mathrm{kg} / \mathrm{d}$} \\
\hline $0.60-0.98$ & 142 & 9.94 & 2.02 & 49.14 & 44.66 & 40.44 \\
\hline $0.99-1.38$ & 265 & 8.98 & 2.00 & 48.03 & 43.38 & 39.05 \\
\hline $1.39-1.77$ & 280 & 8.86 & 1.94 & 49.85 & 45.50 & 41.07 \\
\hline$>2.57$ & 144 & 8.53 & 1.92 & 50.54 & 45.96 & 43.33 \\
\hline \multicolumn{7}{|c|}{ Contrast, $P$-value } \\
\hline Linear & & $* *$ & $* * *$ & $* *$ & NS & $*$ \\
\hline Quadratic & & NS & $* *$ & $* *$ & NS & NS \\
\hline Cubic & & NS & NS & NS & NS & NS \\
\hline
\end{tabular}

${ }^{1} \mathrm{RCT}=$ rennet-coagulation time; $\mathrm{k}_{20}=$ curd-firming time (time to reach a curd firmness of $20 \mathrm{~mm}$ ).

${ }^{2} \mathrm{a}_{30}=30$ min after rennet addition; $\mathrm{a}_{45}=45 \mathrm{~min}$ after rennet addition; $\mathrm{a}_{60}=60$ min after rennet addition.

${ }^{*} P<0.05 ;{ }^{* *} P<0.01 ;{ }^{* * *} P<0.001$. 
the 2 oldest papers cited, RCT values of cow milk are between 10 and $20 \mathrm{~min}$. The average RCT obtained in the present study $(8.6 \mathrm{~min})$ confirmed that sheep milk coagulated much faster than cow milk. Different physicochemical properties, such as larger casein micelles and higher levels of calcium and other minerals per casein weight, may explain this (Park, 2007; Park et al., 2007). This high variability depends on the different breeds but mainly on the experimental conditions. Differences in milk temperature, acidification, and rennet addition cause large differences in MCP in bovine (Okigbo et al., 1985; Mishra et al., 2005) and ovine milk (Ould Eleya et al., 1995; Bencini, 2002; Barłowska et al., 2011).

In cattle, the occurrence of noncoagulating milk samples (NC) is one of the main problems of MCP. Noncoagulating samples are those samples that do not coagulate within $30 \mathrm{~min}$ from rennet addition to milk. They have been very frequently evidenced for both individual and bulk milk samples in cattle (Ikonen et al., 1999), water buffaloes (Cecchinato et al., 2012), sheep (Pazzola et al., 2013; Bittante et al. 2014), and goats (Devold et al., 2011; Pazzola et al., 2012, 2014). The presence of NC samples also affects the actual meaning of average values of MCP and the possibility to estimate breeding values of animals (Ikonen et al., 2004; Cecchinato et al., 2011). Because of this concern, it has been proposed to extend the duration of conventional MCP tests to periods longer than $30 \mathrm{~min}$ for bovine milk (Bittante et al., 2013). In the present study, the incidence of $\mathrm{NC}$ samples was only $0.44 \%$, confirming the excellent coagulation ability of the Sarda sheep.

As in cattle, ovine MCP are strongly affected by experimental conditions. Using the same instrument, temperature, and rennet type and concentration as in the present study but in a different laboratory and environment, Bittante et al. (2014) obtained an average RCT of 6.50 min for milk samples from autochthonous Alpine ewes fed an indoor diet and a value of 9.44 for those receiving the same diet supplemented with CLA. In the present study, the average RCT of Sarda ewes fed pasture and concentrates was between the aforementioned values for the Alpine breeds. Abilleira et al., (2010), using a different instrument, lower temperature $\left(32\right.$ vs. $\left.35^{\circ} \mathrm{C}\right)$, and lower rennet concentration (0.0439 vs. $0.0512 \mathrm{IMCU} / \mathrm{mL}$ ) for bulk milk samples from Latxa ewes, obtained average RCT of about 12 min at the beginning of lactation with indoor feeding and 13 to $15 \mathrm{~min}$ in pasture-fed ewes during mid lactation.

The variability in RCT due to the flock effect was moderate ( $21 \%$ of total variance) and slightly higher than the herd effect for dairy cows (Ikonen et al., 2004; Tyrisevä et al., 2004; Cecchinato et al., 2013). Moreover, the effect of flock size was not significant, despite the concurrent differences in environmental conditions and feeding and management characteristics associated with the flock size of Sardinian farms (Table 1). Similar results have been found in dairy cows, as the effect of management practice and, in particular, of feeding, was not very important in relation to RCT variability (Tyrisevä et al., 2004; Butler et al., 2010).

Among the causes of variation related to RCT in an individual, DIM was the most important in Sarda ewes, confirming previous results reported in dairy cows (Ikonen et al., 2004; Cipolat-Gotet et al., 2012) and Guirra and Manchega ewes (Jaramillo et al., 2008), which consistently show an increase of RCT during lactation. In contrast to those studies, milk from Sarda ewes was characterized by a decrease in RCT during early lactation and an increase in the last stages, so that the shortest coagulation time was registered for milk samples collected from mid-lactation ewes.

In Sarda ewes, coagulation occurs slightly earlier in the first lactation compared with subsequent lactations, confirming the results observed in cows (Cipolat-Gotet et al., 2012), but not those obtained from Guirra and Manchega ewes by Jaramillo et al. (2008) with different instruments and experimental conditions.

Also, daily milk yield level significantly affected RCT of Sarda ewe milk because a decrease in coagulation time was observed in milk samples collected from highyielding compared with low-yielding animals (Table 6). According to the review of Bittante et al. (2012), the phenotypic correlations between RCT and milk yield are moderate or null in dairy cows and more frequently negative (favorable) than positive.

\section{$k_{20}$}

Milk produced by Sarda ewes reached, on average, curd firmness of $20 \mathrm{~mm}\left(\mathrm{k}_{20}\right)$ less than $2 \mathrm{~min}$ after gelation; $20 \mathrm{~mm}$ is usually considered to be the target value for curd cutting. This interval is very short compared with bovine milk, in which $\mathrm{k}_{20}$ is from 5 to $15 \mathrm{~min}$ (Bittante et al., 2012). This trait is seldom reported in large surveys of cattle because a significant proportion of dairy cows produce milk that does not reach the $\mathrm{k}_{20}$ within 30 min of the addition of rennet, which is the standard duration of the lactodynamographic test. The combined effect of rapid gelation and a fast curd-firming process meant that the majority of sheep milk samples reached the $\mathrm{k}_{20}$ within 30 min after rennet addition and, thus, produce a $\mathrm{k}_{20}$ value associated with the sample. For dairy cows, the incidence of samples without a $k_{20}$ value within 30 min varies from a minimum of $8 \%$ in Finnish Friesians (Ikonen et al., 1997) to a maximum of $32 \%$ in German Friesians (Oloffs et al., 1992) and 33\% in Finnish Ayrshires (Ikonen et al., 1999). Due to its 
low average value, the distribution of $\mathrm{k}_{20}$ data was far from normal in ewes of the present study (Figure 1), whereas it is much more close to a Gaussian distribution in cows (Cipolat-Gotet et al., 2012).

In addition, $\mathrm{k}_{20}$ of Sarda ewes' milk was affected by DIM and daily milk yield and it showed a curvilinear trend during lactation, similarly to dairy cows (CipolatGotet et al., 2012). But in the case of sheep, milk with the most favorable $\mathrm{k}_{20}$ was produced at mid lactation, whereas in bovine milk, it occurs at the early or late stages of lactation. The rate of gel firming, measured with different instruments and experimental conditions, has shown a decreasing trend during lactation both in Lacaune (Pellegrini et al., 1997) and in Guirra and Manchega ewes (Jaramillo et al., 2008). The $\mathrm{k}_{20}$ of Sarda sheep showed a curvilinear trend in relation to daily milk yield, with a shortening (improvement) of this trait moving from low-yielding to mid-yielding sheep and a more stable pattern afterward. In Lacaune sheep (Pellegrini et al., 1997), the gel-firming rate was slightly higher in high-yielding than in low-yielding ewes. In dairy cows, the phenotypic correlation between $\mathrm{k}_{20}$ and milk yield was not significant (Ikonen et al., 1997; Cipolat-Gotet et al., 2012).

\section{Curd Firmness}

The $\mathrm{a}_{30}$ of milk samples from Sarda ewes was, on average, $50 \mathrm{~mm}$. The average $\mathrm{a}_{45}$ and $\mathrm{a}_{60}$ values decreased to 46 and $42 \mathrm{~mm}$, respectively, whereas the standard deviation increased. Values of curd firmness, measured with the same technique from Alpine sheep breeds (Bittante et al., 2014), are about 5 to $10 \mathrm{~mm}$ higher than those from Sarda ewes. The results obtained from sheep milk reported here are generally similar to those from autochthonous goat breeds from Sardinia (Pazzola et al., 2011) and Ethiopia (Mestawet et al., 2013) but higher than those obtained from buffaloes (Cecchinato et al., 2012) and especially from dairy cows (CipolatGotet et al., 2012) when a similar quantity of rennet is used.

In the case of dairy cows, the informative value of $\mathrm{a}_{30}$ beyond that of RCT is not very great, because the 2 traits are highly correlated. Compared with sheep, in the bovine species, late gelation and slow curd firming make the $\mathrm{a}_{30}$ strictly dependent on both these traits: the time available for curd firming (30 min minus the $\mathrm{RCT}$ ) is about 1- to 2 -fold the $\mathrm{k}_{20}$, and $\mathrm{a}_{30}$ is about 1 - to 2 -fold $20 \mathrm{~mm}$. Reviewing the results of 9 large studies, Bittante et al. (2012) have found that the phenotypic correlations between $\mathrm{a}_{30}$ and $\mathrm{RCT}$ are, on average, -81 $\pm 10 \%$ and that the corresponding genetic correlations are even higher $(-0.92 \pm 0.05 \%)$.
In the case of the ovine species, the scenario is completely different from cows. For Sarda ewes reported in the present paper, the time available for curd firming in a standard 30-min test $(30 \mathrm{~min}-8.62 \mathrm{~min}=21.38$ min) was much longer: on average, about 11-fold the value of $\mathrm{k}_{20}(21.38 \mathrm{~min} / 1.93 \mathrm{~min}=11.1)$, whereas the $\mathrm{a}_{30}$ was not much greater: about 2.5 -fold $20 \mathrm{~mm}$ (50.21 $\mathrm{mm} / 20 \mathrm{~mm}=2.51)$. This explains the correlation between RCT and $\mathrm{a}_{30}$ in Sarda sheep, which was much lower than in dairy cows (the value of the Pearson correlation between the raw data was $-15 \%$ and the one calculated on residues of the statistical model used was $-23 \%$; Table 3) and about null for $\mathrm{a}_{45}$ and $\mathrm{a}_{60}$. This means that curd firmness in dairy ewes is almost independent of gelation time and that it can hold specific important information that should be better studied.

In Sarda ewes, the decreasing values of average $\mathrm{a}_{30}$, $\mathrm{a}_{45}$, and $\mathrm{a}_{60}(50.21,45.94$, and $42.18 \mathrm{~mm}$, respectively) provides evidence that curd firmness was not continuously increasing toward an asymptotical value, as is often assumed (Bittante, 2011), but apparently decreases. This was interpreted by Bittante et al. (2013) as the effect of curd syneresis causing whey expulsion, as has been recently demonstrated in Alpine sheep breeds (Bittante et al., 2014). The syneresis process is different in ovine and bovine species and it is affected by several technological features (Calvo and Balcones, 2000). Regarding dairy sheep, the pattern of curd firmness depending on time should be better studied to achieve new insights on this species.

Curd-firmness traits of milk from the Sarda breed were significantly influenced by the effect of class of flock size. Moreover, the variability of these traits among the different flocks was much greater than that observed for RCT and $k_{20}$. This last characteristic is not in agreement with results found in different bovine dairy breeds (Tyrisevä et al., 2003; Ikonen et al., 2004), which are characterized by a less significant effect of herd.

In contrast to RCT and $k_{20}$, the sources of variation due to the effects of the individual animal (DIM, parity, and milk yield) slightly affect curd-firmness traits. In particular, Sarda ewes of the present study showed an increase in curd firmness for high-yielding animals and in late stages of lactation, similar to what was observed in the Latxa sheep breed (Abilleira et al., 2010).

\section{CONCLUSIONS}

Milk coagulation properties were studied for the first time on a large number of dairy ewes. Compared with bovine milk, sheep milk was characterized by an earlier gelation, a much more rapid increase in curd firmness 
with time, and a higher $\mathrm{a}_{30}$. It was demonstrated that the correlations between MCP in the ovine and, in particular, in the Sarda sheep breed are much lower than in bovine species and that some of the assumptions and interpretations developed on the latter species cannot be applied to sheep. The effects of Sardinian flock size, as an indicator of management, feeding, and farming system, and individual flock on MCP were quantified as well as the main individual (parity, DIM, and daily milk yield) and technical (cuvette position) causes of variation. It was also evidenced that, in dairy ewes, the gelation, curd-firming, and syneresis processes need further analysis and that the corresponding parameters have to be better defined in relation to environment, management, feeding, genetics of animals, and processing characteristics of milk.

\section{ACKNOWLEDGMENTS}

This research was supported by a grant from the Fondazione Banco di Sardegna (Bank of Sardinia Foundation, Sassari, Italy). The authors thank the farmers for giving access to their flocks; the Provincial Farmers Associations (A.I.P.A./A.P.A.) of Cagliari, Nuoro, Sassari, and Oristano (Italy) for their support in sample collection; and the Regional Farmer Association of Sardinia (A.R.A. Sardegna, Cagliari, Italy) for support in milk analysis.

\section{REFERENCES}

Abilleira, E., M. Virto, A. I. Nájera, J. Salmerón, M. Albisu, F. J. Pérez-Elortondo, J. C. Ruiz de Gordoa, M. de Renobales, and L. J. R. Barron. 2010. Effects of seasonal changes in feeding management under part-time grazing on the evolution of the composition and coagulation properties of raw milk from ewes. J. Dairy Sci. 93:3902-3909.

Agresti, A. 2002. Building and applying logistic regression models. Pages 216-217 in Categorical Data Analysis. John Wiley \& Sons Inc., Hoboken, NJ.

Akaike, H. 1969. Fitting autoregressive models for prediction. Ann. Inst. Stat. Math. 21:243-247.

Ali, A. K. A., and G. E. Shook. 1980. An optimum transformation for somatic cell concentration in milk. J. Dairy Sci. 63:487-490.

Barłowska, J., M. Szwajkowska, Z. Litwińczuk, and J. Król. 2011. Nutritional value and technological suitability of milk from various animal species used for dairy production. Comp. Rev. Food Sci. Food Safety 10:291-302.

Bencini, R. 2002. Factors affecting the clotting properties of sheep milk. J. Sci. Food Agric. 82:705-719.

Bittante, G. 2011. Modeling rennet coagulation time and curd firmness of milk. J. Dairy Sci. 94:5821-5832.

Bittante, G., A. Cecchinato, N. Cologna, M. Penasa, F. Tiezzi, and M. De Marchi. 2011a. Factors affecting the incidence of first-quality wheels of Trentingrana cheese. J. Dairy Sci. 94:3700-3707.

Bittante, G., N. Cologna, A. Cecchinato, M. De Marchi, M. Penasa, F. Tiezzi, I. Endrizzi, and F. Gasperi. 2011b. Monitoring of sensory attributes used in the quality payment system of Trentingrana cheese. J. Dairy Sci. 94:5699-5709.
Bittante, G., B. Contiero, and A. Cecchinato. 2013. Prolonged observation and modelling of milk coagulation, curd firming, and syneresis. Int. Dairy J. 29:115-123.

Bittante, G., E. Pellattiero, F. Malchiodi, C. Cipolat-Gotet, M. Pazzola, G. M. Vacca, S. Schiavon, and A. Cecchinato. 2014. Quality traits and modelling of coagulation, curd firming and syneresis of sheep milk of Alpine breeds fed diets supplemented with rumenprotected conjugated fatty acid. J. Dairy Sci. 97:4018-4028.

Bittante, G., M. Penasa, and A. Cecchinato. 2012. Invited review: Genetics and modeling of milk coagulation properties. J. Dairy Sci. 95:6843-6870.

Butler, S. T., M. A. de Feu, B. O'Brien, T. P. Guinee, and J. J. Murphy. 2010. Short communication: The effect of dry period duration and dietary energy density in early lactation on the rennet gelation properties of milk. J. Dairy Sci. 93:524-528.

Calvo, M. M., and E. Balcones. 2000. Some factors influencing the syneresis of bovine, ovine, and caprine milks. J. Dairy Sci. 83:17331739

Carcangiu, V., M. C. Mura, G. M. Vacca, M. L. Dettori, M. Pazzola, S. Luridiana, and P. P. Bini. 2011. Improvement of the reproductive efficiency for the development of the Sardinian sheep breeding. Pages 82-88 in New Trends for Innovation in the Mediterranean Animal Production, EAAP Scientific Series 129. R. Bouche, A. Derkimba, and F. Casabianaca, ed. Wageningen Academic Publishers, Wageningen, the Netherlands.

Carta, A., S. Casu, and S. Salaris. 2009. Invited review: Current state of genetic improvement in dairy sheep. J. Dairy Sci. 92:58145833 .

Cecchinato, A., C. Cipolat-Gotet, J. Casellas, M. Penasa, A. Rossoni, and G. Bittante. 2013. Genetic analysis of rennet coagulation time, curd-firming rate, and curd firmness assessed over an extended testing period using mechanical and near-infrared instruments. J. Dairy Sci. 96:50-62.

Cecchinato, A., M. Penasa, C. Cipolat-Gotet, M. De Marchi, and G. Bittante. 2012. Short communication: Factors affecting coagulation properties of Mediterranean buffalo milk. J. Dairy Sci. 95:1709-1713

Cecchinato, A., M. Penasa, M. De Marchi, L. Gallo, G. Bittante, and P. Carnier. 2011. Genetic parameters of coagulation properties, milk yield, quality, and acidity estimated using coagulating and noncoagulating milk information in Brown Swiss and HolsteinFriesian cows. J. Dairy Sci. 94:4205-4213.

Cipolat-Gotet, C., A. Cecchinato, M. De Marchi, M. Penasa, and G. Bittante. 2012. Comparison between mechanical and near-infrared methods for assessing coagulation properties of bovine milk. J. Dairy Sci. 95:6806-6819.

Devold, T. G., R. Nordbø, T. Langsrud, C. Svenning, M. J. Brovold, E. S. Sørensen, B. Christensen, T. Ådnøy, and G. E. Vegarud. 2011. Extreme frequencies of the $\alpha_{\mathrm{s} 1}$-casein "null" variant in milk from Norwegian dairy goats-Implications for milk composition, micellar size and renneting properties. Dairy Sci. Technol. 91:39-51.

EU (European Union). 1996. Commission Regulation (EC) No 1263/96 of 1 July 1996 supplementing the Annex to Regulation (CE) No $1107 / 96$ on the registration of geographical indications and designations of origin under the procedure laid down Article 17 of Regulation (ECC) No 2081/92. Off. J. Eur. Union L 163:19-21.

EU (European Union). 2009. Commission Regulation (EC) No 1030/2009 of 29 October 2009 approving minor amendments to the specification of a name registered in the register of protected designations of origin and protected geographical indications (Pecorino Romano (PDO)). Off. J. Eur. Union L 283:43-46.

FAOSTAT (Food and Agriculture Organization of the United Nations Statistics Division). 2013. Statistical Database of the Food and Agriculture Organization of the United Nations. Accessed July 28, 2014. http://faostat3.fao.org/faostat-gateway/go/to/home/E.

ICAR (International Committee for Animal Recording). 2013. Dairy sheep milk survey on-line database. Accessed June 9, 2014. http:// www.survey-icar.org/sheep_survey4/. 
IDF (International Dairy Federation). 2000. Milk - First experiences with automatic flow cytometric determination of total bacterial count in raw milk. IDF 358:2000. IDF, Brussels, Belgium.

IDF (International Dairy Federation). 2006. Milk-Enumeration of somatic cells-Part 2: Guidance on the operation of fluoro-optoelectronic counters. IDF 148-2:2006. IDF, Brussels, Belgium.

Ikonen, T., K. Ahlfors, R. Kempe, M. Ojala, and O. Ruottinen. 1999. Genetic parameters for the milk coagulation properties and prevalence of noncoagulating milk in Finnish dairy cows. J. Dairy Sci. 82:205-214.

Ikonen, T., S. Morri, A.-M. Tyrisevä, O. Ruottinen, and M. Ojala. 2004. Genetic and phenotypic correlations between milk coagulation properties, milk production traits, somatic cell count, casein content, and pH of milk. J. Dairy Sci. 87:458-467.

Ikonen, T., M. Ojala, and E.-L. Syväoja. 1997. Effects of composite casein and $\beta$-lactoglobulin genotypes on renneting properties and composition of bovine milk by assuming an animal model. Agric. Food Sci. Finland 6:283-294.

Jaramillo, D. P., A. Zamora, B. Guamis, M. Rodríguez, and A. J. Trujillo. 2008. Cheesemaking aptitude of two Spanish dairy ewe breeds: Changes during lactation and relationship between physico-chemical and technological properties. Small Rumin. Res. 78:48-55.

Macciotta, N. P. P., A. Cappio-Borlino, and G. Pulina. 1999. Analysis of environmental effects on test day milk yields of Sarda dairy ewes. J. Dairy Sci. 82:2212-2217.

McMahon, D. J., and R. J. Brown. 1982. Evaluation of Formagraph for comparing rennet solutions. J. Dairy Sci. 65:1639-1642.

Mestawet, T. A., A. Girma, T. Ådnøy, T. G. Devold, and G. E. Vegarud. 2013. Newly identified mutations at the CSN1S1 gene in Ethiopian goats affect casein content and coagulation properties of their milk. J. Dairy Sci. 96:4857-4869.

Mishra, R., S. Govindasamy-Lucey, and J. A. Lucey. 2005. Rheological properties of rennet-induced gels during the coagulation and cutting process: Impact of processing conditions. J. Texture Stud. 36:190-212.

Okigbo, L. M., G. H. Richardson, R. J. Brown, and C. A. Ernstrom. 1985. Interaction of calcium, $\mathrm{pH}$, temperature, and chymosin during milk coagulation. J. Dairy Sci. 68:3135-3142.

Oloffs, K., H. Schulte-Coerne, K. Pabst, and H. O. Gravert. 1992. Die Bedeutung der Proteinvarianten für genetische Unterschiede in der Käsereitauglichkeit der Milch. Züchtungskunde 64:20-26.

Ould Eleya, M. M., S. Desobry Banon, and J. Hardy. 1995. A comparative study of $\mathrm{pH}$ and temperature effects on the acidic coagulation of milk from cows, goats, and sheep. J. Dairy Sci. 78:2675-2682.
Park, Y. W. 2007. Rheological characteristics of goat and sheep milk. Small Rumin. Res. 68:73-87.

Park, Y. W., M. Juárez, M. Ramos, and G. F. W. Haenlein. 2007. Physico-chemical characteristics of goat and sheep milk. Small Rumin. Res. 68:88-113.

Pazzola, M., F. Balia, V. Carcangiu, M. L. Dettori, G. Piras, and G. M. Vacca. 2012. Higher somatic cells counted by the electronic counter method do not influence renneting properties of goat milk. Small Rumin. Res. 102:32-36.

Pazzola, M., F. Balia, M. L. Dettori, M. C. Mura, V. Carcangiu, and G. M. Vacca. 2011. Effects of different storage conditions, the farm and the stage of lactation on renneting parameters of goat milk investigated using the Formagraph method. J. Dairy Res. 78:343-348.

Pazzola, M., M. L. Dettori, E. Pira, A. Noce, P. Paschino, and G. M. Vacca. 2014. Effect of polymorphisms at the casein gene cluster on milk renneting properties of the Sarda goat. Small Rumin. Res. 117:124-130.

Pazzola, M., M. L. Dettori, G. Piras, E. Pira, F. Manca, O. Puggioni, A. Noce, and G. M. Vacca. 2013. The effect of long-term freezing on renneting properties of Sarda sheep milk. Agric. Conspec. Sci. $78: 275-279$.

Pellegrini, O., F. Remeuf, M. Rivemale, and F. Barillet. 1997. Renneting properties of milk from individual ewes: Influence of genetic and non-genetic variables, and relationship with physicochemical characteristics. J. Dairy Res. 64:355-366.

Ramos, M., and M. Juárez. 2011. Sheep Milk. Pages 494-502 in Encyclopedia of Dairy Sciences. 2nd ed. Vol. 1. J. W. Fuquay, P. F. Fox, and P. L. H. McSweeney, ed. Academic Press, San Diego, CA.

Tyrisevä, A.-M., T. Ikonen, and M. Ojala. 2003. Repeatability estimates for milk coagulation traits and non-coagulation of milk in Finnish Ayrshire cows. J. Dairy Res. 70:91-98.

Tyrisevä, A.-M., T. Vahlsten, O. Ruottinen, and M. Ojala. 2004. Noncoagulation of milk in Finnish Ayrshire and Holstein-Friesian cows and effect of herds on milk coagulation ability. J. Dairy Sci. 87:3958-3966.

Vacca, G. M., V. Carcangiu, M. L. Dettori, M. Pazzola, M. C. Mura, S. Luridiana, and G. Tilloca. 2008. Productive performance and meat quality of Mouflon $\times$ Sarda and Sarda $\times$ Sarda suckling lambs. Meat Sci. 80:326-334.

Vacca, G. M., A. Dhaouadi, M. Rekik, V. Carcangiu, M. Pazzola, and M. L. Dettori. 2010. Prolificacy genotypes at BMPR 1B, BMP15 and GDF9 genes in North African sheep breeds. Small Rumin. Res. 88:67-71. 